\title{
PERTANGGUNGJAWABAN PIDANA KORPORASI (PT) ATAS TINDAK PIDANA PERUSAKAN LINGKUNGAN HIDUP
}

\author{
Erni Juniria Harefa ${ }^{1}$, Pondang Hasibuan ${ }^{2}$, Sahat Benny Risman Girsang ${ }^{3}$, Herlina \\ Manullang ${ }^{4}$ \\ ${ }^{123}$ Advokat di Kota Pematangsiantar \\ ${ }^{4}$ Program Studi Magister Hukum \\ Program Pascasarjana \\ Universitas HKBP Nommensen, Medan-Sumatera Utara-Indonesia \\ e-mail: ernijuniriahrf@gmail.com
}

\begin{abstract}
The occurrence of environmental crimes in the form of environmental pollution and/or destruction, mostly carried out in the context of running an economic business, and is also the attitude of the authorities and entrepreneurs who do not carry out or neglect their obligations in environmental management. Environmental pollution and/or destruction continues to increase in line with the increase in industrial activities or the like, of course the environment needs legal protection. Article 116 of the Environmental Protection and Management Law (UUPPLH), makes the concept of corporate criminal responsibility and corporate management (directors, managers who are responsible for managing the company's environment, can even be asked to shareholders and commissioners) together, in the event that the activities and/or business of the corporation cause environmental pollution and/or destruction. On the other hand, the accountability of the directors/management of the corporation is also needed because there is a possibility that the sanctions imposed on the corporation will not affect the lives of the leaders/management of the corporation. The method used in this thesis research is normative juridical research using primary, secondary, and tertiary legal materials. This study uses library research techniques, which are then analyzed qualitatively. Based on the results of the study, that corporate criminal liability in Article 116 paragraph (1) UUPPLH is based on the identification of Theory and Vicarious Liability. Meanwhile, the director's criminal responsibility as an individual for criminal acts of environmental destruction occurs as long as the director has the authority to prevent violations or to improve the situation. Meanwhile, the criminal responsibility of the director representing the PT organ for environmental crimes can be identified based on the Responsible Corporate Officer Doctrine (RCO) and Strict Liability, because his position in the company has an obligation to take action to ensure that the violation will not occur as stipulated in Article 116 and 117 UUPPLH.
\end{abstract}

Keywords : Criminal Liability, Corporate (PT), Director, and Environmental Damage

\begin{abstract}
Abstrak
Pencemaran dan/atau perusakan lingkungan terus meningkat sejalan dengan meningkatnya kegiatan industri atau sejenisnya, tentunya lingkungan hidup perlu mendapatkan perlindungan hukum. Pasal 116 UUPPLH menjadikan konsep pertanggungjawaban pidana korporasi dan pengurus korporasi (direktur, para manager yang bertanggungjawab dalam pengelolaan lingkungan hidup perusahaan, bahkan dapat dimintakan kepada para pemegang saham maupun para komisaris) secara bersama-sama, dalam hal kegiatan dan/atau usaha korporasi tersebut menyebabkan terjadinya pencemaran dan/atau perusakan lingkungan hidup. Pada sisi lain pertanggungjawaban direktur/pengurus korporasi juga diperlukan karena adanya adanya kemungkinan bahwa sanksi denda yang dijatuhkan kepada korporasi tidak
\end{abstract}


akan mempengaruhi kehidupan pemimpin/pengurus korporasi. Metode yang digunakan dalam penelitian tesis ini adalah penelitian yuridis normative dengan menggunakan bahanbahan hukum primer, sekunder, dan tersier. Penelitian ini menggunakan tehnik penelitian kepustakaan, yang selanjutnya dianalisis secara kualitatif. Berdasarkan hasil penelitian, bahwa pertanggungjawaban pidana korporasi di dalam Pasal 116 ayat (1) UUPPLH di dasarkan kepada identifikasi Theory dan Vicarious Liability. Sedangkan pertanggungjawaban pidana direktur sebagai individu atas tindak pidana perusakan lingkungan hidup terjadi selama direktur itu memiliki wewenang untuk mencegah terjadinya pelanggaran atau untuk memperbaiki keadaan. Sedangkan pertanggungjawaban pidana direktur mewakili organ PT atas tindak pidana lingkungan hidup dapat diidentifikasi berdasarkan Responsible Corporate Officer Doctrine (RCO) dan Strict Liability, oleh karena posisinya dalam perusahaan memiliki kewajiban untuk mengambil tindakan untuk memastikan bahwa pelanggaran tersebut tidak akan terjadi sebagaimana diatur dalam Pasal 116 dan 117 UUPPLH.

Kata Kunci : Pertanggungjawaban Pidana, Korporasi (PT), Direktur dan Perusakan Lingkungan Hidup

\section{A. Pendahuluan}

Pasal 28 ayat (1) UUD 1945 menyatakan "setiap orang berhak hidup sejahtera lahir batin, bertempat tinggal dan mendapatkan lingkungan hidup yang baik dan sehat serta memperoleh pelayanan kesehatan." Rumusan pasal ini memandang bahwa kebutuhan mendapatkan lingkungan yang sehat adalah salah satu hak asasi manusia. Negara berkewajiban memberi perlindungan dan jaminan lingkungan sehat, oleh karena itu negara harus memiliki otoritas kuat dalam mengelola dan melindungi lingkungan hidup. ${ }^{1}$

Hukum lingkungan telah berkembang dengan pesat, bukan saja dalam hubungannya dengan fungsi hukum sebagai perlindungan, pengendalian dan kepastian hukum bagi masyarakat (social control) dengan peran agent of stability, tetapi lebih menonjol lagi sebagai sarana pembangunan (a tool of social engineering) dengan peran sebagai agent of development atau agent of change. Sebagai disiplin ilmu hukum yang sedang berkembang, sebagian besar materi hukum lingkungan merupakan bagian dari hukum administrasi (administratief recht), telah menimbulkan pembidangan dalam hukum lingkungan administrasi, hukum lingkungan keperdataan dan hukum lingkungan kepidanaan.

Persoalan lingkungan menjadi semakin kompleks, tidak hanya bersifat praktis, konseptual, ekonomi saja, tetapi juga merupakan masalah etika baik sosial maupun bisnis. Hukum pidana tidak hanya melindungi alam, flora dan fauna (the ecological approach), tetapi juga masa depan kemanusiaan yang kemungkinan menderita akibat degradasi lingkungan hidup (the antropocentris approach). Dengan demikian muncul istilah "the environmental laws carry penal sanction that protect a multimedia of interest".

Perkembangan undang-undang tentang lingkungan hidup khususnya di Indonesia, tidak dapat dipisahkan dari gerakan sedunia untuk memberikan perhatian lebih besar kepada lingkungan hidup, mengingat kenyataan bahwa lingkungan hidup telah menjadi masalah yang perlu ditanggulangi bersama demi kelangsungan hidup di dunia ini. ${ }^{2}$

Perlindungan dan pengelolaan lingkungan hidup di Indonesia pada dasarnya bertujuan untuk melindungi wilayah Negara Kesatuan Republik Indonesia dari pencemaran atau kerusakan lingkungan hidup. Selain itu juga menjamin keselamatan, kesehatan, dan

\footnotetext{
${ }^{1}$ N.H.T. Siahaan, 2009, Hukum Lingkungan, Pancuran Alam, Jakarta, hlm. 4

2 Tony Samuel, Penerapan Tindak Pidana Lingkungan Bagi Korporasi Dalam Penegakan Hukum Lingkungan, Socioscientia Jurnal Ilmu Ilmu Sosial, Volume 8 No 1 Maret 2016, hlm. 175
} 
kehidupan manusia, menjamin kelangsungan kehidupan makhluk hidup dan kelestarian ekosistem serta pelestarian fungsi lingkungan dalam rangka pembangunan berkelanjutan agar terpenuhinya keadilan bagi generasi masa kini dan generasi masa depan. ${ }^{3}$ Untuk menjamin adanya kepastian hukum agar masyarakat mempunyai kesadaran untuk turut serta dalam melestarikan lingkungan hidup, pemerintah telah menyiapkan perangkat hukum khususnya hukum lingkungan untuk menjerat para pencemar dan perusakan lingkungan hidup. Undangundang yang dimaksud adalah Undang-Undang Nomor 4 Tahun 1982 tentang Lingkungan Hidup (UULH) serta Undang-Undang Nomor 23 Tahun 1997 tentang Pengelolaan Lingkungan Hidup (UUPPLH) dan disempurnakan dengan Undang-Undang Nomor 32 Tahun 2009 tentang Perlindungan dan Pengelolaan Lingkungan Hidup (disingkat UUPPLH).

Tindak pidana terhadap lingkungan hidup yang terjadi pada masa kini maupun masa yang akan datang, sebagian besar dilakukan oleh korporasi atau perusahaan, karena perusahaan merupakan suatu produsen yang memasok kebutuhan masyarakat secara langsung telah banyak mengeluarkan polusi, antara lain polusi udara, tanah maupun air. ${ }^{4} \mathrm{KUHP}$ belum mengakui keberadaan korporasi sebagai subyek hukum pidana. hanya mengenal orang (person) sebagai pelaku tindak pidana. Apabila tindak pidana dilakukan oleh orang-orang yang ada dalam korporasi, maka yang bertanggungjawab adalah pengurus yang secara riil melakukan tindak pidana, sebagaimana diatur dalam Pasal 59 KUHP. Pada perkembangan Mahkamah Agung (MA) telah menerbitkan Peraturan Mahkamah Agung No.13 Tahun 2016 Tentang Tata Cara Penanganan Perkara Tindak Pidana Oleh Korporasi (selanjutnya disebut Perma No 13 Tahun 2016) mengakui korporasi sebagai pelaku tindak pidana dan dapat dipertanggungjawabkan.

UUPPLH telah mengatur pertanggungjawaban pidana korporasi. Pada intinya UUPPLH menyebutkan pertanggungjawaban pidana dapat dimintakan kepada setiap orang, badan hukum atau pengurusnya. Perluasan subyek hukum di dalam UUPLLH merupakan kekhususan tindak pidana diluar KUHP, akan tetapi keberadaan badan hukum sebagai subyek hukum telah diakui di dalam RUU KUHP 2019. Menurut Alvi Syahrin, pertanggungjawaban pidana korporasi, setidak tidaknya dibagi dalam beberapa bentuk, yaitu: ${ }^{5}$

1. Pengurus korporasi sebagai pembuat penguruslah yang bertanggungjawab

2. Korporasi sebagai pembuat dan penguruslah yang bertanggungjawab.

3. Korporasi sebagai pembuat, korporasi sebagai bertanggungjawab

4. Korporasi dan pengurus yang berbuat korporasi dan pengurus yang bertanggungjawab.

Menentukan pertanggungjawaban korporasi merupakan hal yang sulit bagi aparat penegak hukum. Aparat penegak hukum dalam meminta pertanggungjawaban korporasi perlu memperhatikan apakah korporasi melakukan pelanggaran terhadap gangguan publik dan apakah sanksi pidana yang dijatuhkan akan mencapai antara tujuan hukum pidana dan infesiensi sosial ekonomi yang dihasilkan dari aplikasi pertanggungjawaban pidana korporasi. Pasal 116 Undang-Undang Perlindungan dan Pengelolaan Lingkungan Hidup (UUPPLH), menjadikan konsep pertanggungjawaban pidana korporasi dan pengurus korporasi (direktur, para manager yang bertanggungjawab dalam pengelolaan lingkungan hidup perusahaan, bahkan dapat dimintakan kepada para pemegang saham maupun para komisaris) secara bersama-sama, dalam hal kegiatan dan/atau usaha korporasi tersebut menyebabkan terjadinya pencemaran dan/atau perusakan lingkungan hidup. Selanjutnya Pasal 116 UUPPLH menyebutkan antara lain:

\footnotetext{
${ }^{3}$ Pasal 3 UU No 32 Tahun 2009 tentang Perlindungan dan Pengelolaan Lingkungan Hidup (UUPPLH)

${ }^{4}$ Andi Hamzah, 2005, Penegakan Hukum Lingkungan, Jakarta, Sinar Grafika, hlm.6

${ }^{5}$ Alvi Syahrin, dkk, 2019, Ketentuan Pidana Korporasi Tentang Perlindungan dan Pengelolaan Lingkungan Hidup, Jakarta, Kencana, hlm 28-30.
} 
1. Apabila ketentuan pidana lingkungan hidup dilakukan oleh, untuk, atau atas nama badan usaha, tuntutan pidana dan sanksi pidana dijatuhkan kepada badan usaha dan/atau orang yang memberi perintah untuk melakukan tindak pidana tersebut atau orang yang bertindak sebagai pemimpin kegiatan dalam tindak pidana tersebut.

2. Apabila tindak pidana lingkungan hidup sebagaimana dimaksud pada ayat (1) dilakukan oleh orang, yang berdasarkan hubungan kerja atau berdasarkan hubungan lain bertindak dalam lingkup kerja badan usaha, sanksi pidana dijatuhkan terhadap pemberi perintah atau pemimpin dalam tindak pidana tersebut tanpa memperhatikan tindak pidana tersebut dilakukan secara sendiri atau bersama sama.

Ketentuan Pasal 116 UUPPLH mengatur tentang pertanggungjawaban pidana dalam hal tindak pidana dilakukan oleh, untuk dan atas nama badan usaha. Sehubungan dengan pertanggungjawaban pidana harus jelas terlebih dahulu mengenai siapa yang dapat dipertanggungjawabkan. Artinya, harus terlebih dahulu dipastikan siapa yang dinyatakan sebagai pembuat tindak pidana tersebut. Mengenai siapa yang dinyatakan sebagai pembuat tindak pidana (subyek tindak pidana) pada umumnya sudah dirumuskan oleh pembuat undang-undang. ${ }^{6}$ Pasal 116 UUPPLH telah membuka kemungkinan apabila suatu badan usaha melakukan perbuatan pidana, tidak hanya yang dituntut badan usahanya saja, tetapi orang yang telah memerintahkan kejadian tersebut dan orang yang memimpin sendiri secara nyata perbuatan yang dilarang. Artinya, pengurus sebagai pemberi perintah dan/atau pemimpin tindakan nyata dapat dipertanggungjawabkan atas perbuatan yang dilakukan oleh badan usaha. Berdasarkan uraian latar belakang diatas maka rumusan masalah antara lain, pertama, bagaimana pertanggungjawaban pidana korporasi (PT) bila melakukan tindak pidana perusakan lingkungan lingkungan hidup? Kedua, kapan Direktur PT bertanggungjawab mewakili organ perseroan terbatas (PT) atas tindak pidana perusakan lingkungan hidup ?

\section{B. Metode Penelitian}

Menurut Peter Mahmud Marzuki, penelitian hukum dilakukan untuk mencari pemecahan atas isu hukum yang timbul, yaitu memberikan preskripsi mengenai apa yang seyogyanya atas isu yang diajukan. Preskripsi diartikan apa yang diharuskan. Lebih lanjut Peter menyatakan bahwa penelitian hukum adalah suatu proses untuk menemukan aturan hukum, maupun doktrin-doktrin hukum guna menghadapi isu hukum yang dihadapi. ${ }^{7}$ Jenis penelitian yang dipergunakan adalah penelitian hukum normatif atau penelitian kepustakaan, sehingga penelitian ini memfokuskan untuk menelaah dan menganalisis norma-norma hukum, asasasas hukum yang terdapat di dalam undang-undang lingkungan hidup, beserta peraturanperaturan lainnya yang berkaitan dengan objek penelitian. ${ }^{8}$

Pendekatan penelitian yang dipergunakan adalah pendekatan perundang-undangan (statute approach). Pendekatan perundang-undangan (statute approach) dilakukan dengan mengkaji peraturan perundang-undangan dan regulasi yang bersangkut paut dengan isu hukum yang sedang diteliti. Bagi peneliti pendekatan perundang-undangan ini akan membuka kesempatan bagi peneliti untuk mempelajari adakah konsistensi dan kesesuaian antara satu jenis peraturan perundang-undangan dengan peraturan yang lainnya atau antara regulasi dan undang-undang. ${ }^{9}$

\footnotetext{
${ }^{6}$ Mulyadi dan Dwidja Priyatno, 1991, Pertanggungjawaban Pidana Korporasi Dalam Hukum Pidana, , Sekolah Tinggi Hukum, Bandung, hlm. 66-67.

${ }^{7}$ Dyah Ochtorina Susanti, A' an Efendi, 2014, Penelitian Hukum (Legal Research), Sinar Grafika, Jakarta, hlm 1-3

${ }^{8}$ Soerjono, Soekanto dan Sri Mamudji, Penelitian Hukum Normatif, Suatu Tinjauan Singkat, Raja Grafindo Persada, Jakarta, 1995, hlm. 12

${ }^{9}$ Johnny Ibrahim, 2006, Teori dan Metodologie Penelitian Hukum Normatif, Bayumedia, Surabaya, hlm .192.
} 
http://ejournal.uhn.ac.id/index.php/opinion

Sesuai dengan jenis penelitian yang dipergunakan maka sumber data yang dipergunakan adalah data sekunder. ${ }^{10}$ Sumber data sekunder dapat diklasifikasikan dengan bahan hukum primer berkaitan dengan Pertanggungjawaban Pidana Korporasi (PT) Atas Tindak Pidana Baku Mutu Lingkungan, terdiri dari; UUPT, Undang-Undang No.32 Tahun 2009 tentang Perlindungan dan Pengelolaan Lingkungan Hidup. (UUPPLH) dan Undang-Undang yang berkaitan dengan Perlindungan dan Pengelolaan Lingkungan Hidup, seperti UU No 18 Tahun 2013 tentang Pencegahan dan Pemberantasan Perusakan Hutan, UU No 18 Tahun 2004 tentang Perkebunan sebagaimana telah diubah dan diganti dengan UU No 39 Tahun 2014. Bahan hukum sekunder yaitu bahan-bahan yang memberikan penjelasan mengenai bahan hukum primer, seperti: buku-buku atau literatur yang terkait dengan judul tesis yang diteliti, hasil karya ilmiah yang relevan dalam penelitian ini, dan bahan hukum penunjang lainnya yang relevan dalam penelitian ini. Bahan hukum tersier yaitu semua dokumen yang berisi tentang konsep-konsep dan keterangan-keterangan yang mendukung bahan hukum primer dan bahan hukum sekunder, seperti kamus, ensklopedia dan sebagainya.

\section{Pembahasan}

\section{Pertanggungjawaban Pidana Korporasi}

Pertanggungjawaban pidana merupakan diteruskannya celaan obyektif yang ada pada tindak pidana, dan secara subyektif kepada seorang yang memenuhi syarat untuk dapat dijatuhi pidana karena perbuatannya. Pemikiran dimintainya pertanggungjawaban pidana korporasi ${ }^{11}$ mengalami perkembangan. Pertanggungjawaban pidana korporasi saat ini, diotorisasi lebih dari satu dasar untuk meminta pertanggungjawaban pidana korporasi, baik berdasarkan pertanggungjawaban atas respondeat superior maupun pertanggungjawaban atas kesalahan organisasi secara keseluruhan.

Mengintegrasikan pertanggungjawaban pidana berdasarkan respondeat superior dan kesalahan organisasi korporasi berarti pertanggungjawaban pidana korporasi dapat berdasarkan atas dasar prilaku individu karyawan korporasi atau berdasarkan kegagalan korporasi dalam menjalankan organisasionalnya atau korporasi belum mengambil langkahlangkah yang memadai dalam mencegah terjadinya tindak pidana. Korporasi juga dapat diminta pertanggungjawaban pidana atas tindakan atau kelalaian yang dilakukan oleh "perwakilannya". "Perwakilan" korporasi termasuk para karyawan, para agen atau kontraktor serta dari beberapa perwakilan secara bersama-sama sehingga terwujud suatu tindak pidana.

Terhadap tindak pidana yang pertanggungjawaban pidananya mensyaratkan adanya mens rea dari pelakunya, menjadikan suatu korporasi dapat dimintai pertanggungjawaban dalam hal perbuatan dilakukan maupun adanya keterlibatan dari karyawan pada level tinggi (senior official). Hal ini sejalan dengan perluasan pertanggungjawaban pidana korporasi atas perbuatan para karyawannya termasuk memperluas pengertian dari orang/karyawan pada level tinggi (senior official) yang dianggap sebagai yang mengarahkan pikiran (directing mind) termasuk orang atau karyawan yang memainkan peran penting dalam pembentukan kebijakan organisasi atau bertanggungjawab untuk mengelola jalannya kegiatan operasional korporasi. Selanjutnya, korporasi juga dimintai pertanggungjawaban dalam hal terjadinya pembiaran termasuk kegagalan seorang pejabat senior (senior official) untuk mengambil langkah-langkah

\footnotetext{
${ }^{10}$ Simamora, Janpatar., Analisa Yuridis Terhadap Model Kewenangan Judicial Review di Indonesia, Jurnal Mimbar Hukum Fakultas Hukum Universitas Gadjah Mada Yogyakarta, Vol. 25 No. 3 Oktober 2013, hlm. 388-401.

${ }^{11}$ Alvi Syahri, 2019, Pertanggungjawaban Pidana Korporasi dalam Undang-Undang No 32 Tahun 2019 tentang Perlindungan dan Pengelolaan Lingkungan Hidup, Makalah Disampaikan pada "Simposium Nasional, Pelatihan Hukum Pidana dan Kriminologi” MAHUPIKI, 3 April 2018, Padang
} 
pencegahan karena mengetahui bahwa seseorang wakil dari perusahaan (officer) itu akan melakukan pelanggaran.

Dengan demikian, dimintakannya pertanggungjawaban pidana bagi korporasi tidak hanya didasarkan kepada keadaan mental (mens rea) tetapi dilihat dari perilaku korporasi. Perilaku korporasi dapat berupa kelalaian yang terjadi dalam hal secara keseluruhan (dalam hal ini dengan menghimpun tingkah laku officer, agen atau pejabat) menyebabkan terjadinya tindak pidana, atau manajemen memperlihatkan tindakan yang tidak memadai atau gagal menyediakan sistem yang layak untuk memastikan informasi yang akan diterima para karyawan yang melaksanakan operasional/jalannya korporasi sehingga menyebabkan terjadinya tindak pidana, karena korporasi dianggap sebagai "mendorong", "mengarahkan", "mentoleransi atau menyebabkan ketidak patuhan" terjadinya tindak pidana.

\section{Pertanggungjawaban Pidana Korporasi (PT) Bila Melakukan Tindak Pidana Perusakan Lingkungan Hidup}

Ketentuan mengenai pertanggungjawaban pidana korporasi diatur di dalam Pasal $116 \mathrm{~s} / \mathrm{d}$ 120 UU No 32 Tahun 2009 tentang Perlindungan dan Pengelolaan Lingkungan Hidup (selanjutnya disebut UUPPLH). Pasal 116 UUPPLH menyatakan :

1. Apabila tindak pidana lingkungan hidup dilakukan oleh, untuk, atau atas nama badan usaha, tuntutan pidana dan sanksi pidana dijatuhkan kepada Badan usaha dan/atau orang yang memberi perintah untuk melakukan tindak pidana tersebut atau orang yang bertindak sebagai pemimpin kegiatan dalam tindak pidana tersebut.

2. Apabila tindak pidana lingkungan hidup sebagaimana dimaksud pada ayat (1) dilakukan oleh orang, yang berdasarkan hubungan kerja atau berdasarkan hubungan lain yang bertindak dalam lingkup hubungan kerja atau berdasarkan hubungan lain yang bertindak dalam lingkup kerja badan usaha, sanksi pidana dijatuhkan terhadap pemberi perintah atau pemimpin dalam tindak pidana tersebut tanpa memperhatikan tindak pidana tersebut dilakukan secara sendiri atau bersama-sama.

Ketentuan Pasal 116 UUPPLH mengatur tentang pertanggungjawaban pidana dalam hal tindak pidana dilakukan oleh, untuk dan atas nama badan usaha. Sehubungan dengan pertanggungjawaban pidana harus jelas terlebih dahulu mengenai siapa yang dapat dipertanggungjawabkan. Artinya, harus terlebih dahulu dipastikan siapa yang dinyatakan sebagai pembuat tindak pidana tersebut. Mengenai siapa yang dinyatakan sebagai pembuat tindak pidana (subyek tindak pidana) pada umumnya sudah dirumuskan oleh pembuat undang-undang. ${ }^{12}$

Badan usaha sebagaimana di dalam Pasal 1 ayat (32) UUPPLH adalah orang perorangan atau badan usaha baik yang berbadan hukum atau badan usaha yang tidak berbadan hukum. Konsep badan usaha dijumpai dalam KUHPerdata, diantaranya (Pasal 1618 KUHPerdata-1652 KUHPerdata), perkumpulan (Pasal 1653 KUHPerdata-Pasal 1665 KUHPerdata) yaitu Firma (Pasal 16 KUHD-Pasal 35 KUHD) dan Komanditer (Pasal 16 KUHD-Pasal 35 KUHD). Merujuk penjelasan ini maka Perseroan Terbatas adalah dikategorikan sebagai badan usaha atau korporasi dan sebagai subyek hukum tindak pidana lingkungan hidup.

Korporasi (PT) sebagai pelaku tindak pidana perusakan lingkungan perlu memperhatikan kasus perkasus sesuai dengan sifat kekhasan tindak pidana tertentu yang bisa berupa tindak pidana fungsional yang lebih bersifat administratif dan tindak pidana nonfungsional yang lebih bersifat fisik, perlu dipedomani atau memperhatikan bahwa:

\footnotetext{
${ }^{12}$ Mulyadi dan Dwidja Priyatno, Pertanggungjawaban Pidana Korporasi, Prenada, Jakarta, hlm. 66-67.
} 
1. Perbuatan dari orang perorangan dapat dibebankan kepada korporasi (PT), apabila perbuatan-perbuatan tersebut tercermin dalam lalu lintas sosial sebagai perbuatanperbuatan korporasi:

2. Apabila sifat dan tujuan dari pengaturan telah menunjukkan indikasi untuk pembuat pidana, untuk pembuktian akhir pembuat pidana, di samping apakah perbuatan tersebut sesuai dengan tujuan statute (anggaran dasar dan anggaran rumah tangga) dari korporasi (PT) dan atau sesuai dengan kebijaksanaan korporasi (PT) dalam arti tindakan atau perbuatan tersebut sesuai dengan ruang lingkup pekerjaan korporasi (PT):

3. Perbuata yang terlarang yang untuk mempertanggungjawabkannya dibebankan kepada korporasi (PT) dilakukan dalam rangka pelaksanaan tugas dan atau pencapaian tujuantujuan korporasi (PT) tersebut :

4. Perbuatan pengurus korporasi (PT) dianggap sebagai perbuatan korporasi (PT) itu sendiri dalam hal pengurus korporasi (PT) mempunyai kewenangan atau kekuasaan dalam hal (untuk) menentukan apakah perbuatan itu harus merupakan bagian dari perbuatan-perbuatan yang menurut kenyataan diterima atau lazimnya diterima korporasi (PT). Syarat kekuasaan (machtsvereiste) mencakup: wewenang mengatur/menguasasi dan atau memerintah pihak yang dalam kenyatanaan melakukan tindak pidana lingkungan; mampu melaksanakan wewenangnya dan pada dasarnya mampu mengambil keputusan-keputusan tentang hal yang bersangkutan; dan mampu mengupayakan kebijakan atau tindakan pengamanan dalam rangka mencegah dilakukannya tindak pidana lingkungan. Selanjutnya, syarat penerimaan atau akseptasi (aanvaardingvereiste) terjadi apabila ada kaitan era tantara proses pengambilan atau pembentukan keputusan korporasi (PT) dengan tindak pidana lingkungan yang dilakukan termasuk juga adanya kemampuan pengawasan secara cukup. Dengan demikian, perbuatan karyawan korporasi (PT) hanya akan dipertimbangkan sebagai perbuatan pimpinan korporasi, apabila : 1. Perbuatan dalam kerangka kewenangannya untu menentukan pegawai termasuk untuk berbuat ; 2 . Perbuatan karyawan masuk dalam kategori perbuatan yang accepted oleh korporasi (PT) dalam kerangka bisnis yang normal.

5. Kesengajaan korporasi (PT) terjadi dalam hal kesengajaan itu pada kenyataannya tercakup dalam politik atau tujuan korporasi (PT), atau berada dalam kegiatan yang nyata dari korporasi (PT) tersebut. Kesengajaan korporasi juga bisa timbul dalam hal kesengajaan dari perorangan (natuurlijk person) yang berbuat atas nama korporasi (PT)

6. Kesengajaan suatu organ dari korporasi (PT) dapat dipertanggungjawabkan secara hukum. Dalam hal tertentu, kesengajaan dari seorang bawahan bahkan dari orang/pihak ketiga, dapat mengakibatkan kesengajaan korporasi, artinya, hanya tindakan sengaja fungsionaris pimpinan korporasi yang dapat diatribusikan pada korporasi, tetapi juga termasuk tindakan pegawai/karyawan rendahan.

7. Pertanggungjawaban pidana juga bergantung kepada organisasi internal dalam korporasi (PT) dan cara bagaimana pertanggungjawaban dibagi, demikian juga halnya dengan kealpaan;

8. Pengetahuan Bersama dari Sebagian besar anggota direksi atau pengurus korporasi (PT) dapat dianggap sebagai kesengajaan korporasi (PT), bahkan sampai kepada kesengajaan berinsyaf (sadar akan) kemungkinan atau opzet mogelijkheids bewustzijn atau dolus evantualis.

Berdasarkan pasal 116 ayat (1) UUPPLH, dalam hal tindak pidana dilakukan oleh, untuk dan atas nama korporasi (PT), yang dapat dituntut dan dijatuhkan hukuman, yaitu; 
1. Korporasi (PT) dan orang yang memberi perintah untuk melakukan tindak pidana lingkungan;

2. Korporasi (PT) dan orang yang bertindak sebagai pemimpin kegiatan dalam tindak pidana lingkungan;

3. Korporasi (PT)

4. Orang yang memberi perintah untuk melakukan tindak pidana lingkungan hidup;

5. Orang yang bertindak sebagai pemimpin kegiatan dalam tindak pidana;

Selanjutnya Pasal 116 ayat (2) UUPPLH, dalam hal tindak pidana dilakukan oleh, untuk dan atas nama korporasi (PT) dan tindak pidana itu dilakukan oleh orang yang berdasarkan hubungan kerja atau hubungan lain, yang dapat dituntut dan dijatuhkan hukuman, yaitu;

1. Pemberi perintah dalam hal tindak pidana lingkungan tanpa memperhatikan tindak pidana tersebut dilakukan secara sendiri atau Bersama-sama;

2. Pemimpin dalam tindak pidana lingkungan tanpa memperhatikan tindak pidana tersebut dilakukan secara sendiri atau Bersama.

Frasa "orang yang memberi perintah untuk melakukan tindak pidana" dan" orang yang bertindak sebagai pemimpin kegiatan dalam tindak pidana" sebagaimana disebutkan dalam Pasal 116 UUPPLH merupakan sebagai orang yang dapat dimintakan pertanggungjawaban pidana. Ketentuaan Pasal 116 ayat (1) UUPPLH membuka kemungkinan apabila suatu korporasi (PT) melakukan perbuatan pidana, tidak hanya yang dituntut korporasi (PT) saja tetapi juga orang yang memerintahkan kejadian tersebut dan orang yang memimpin sendiri secara nyata perbuatan yang dilarang, Artinya, pengurus sebagai pemberi perintah dan/atau pemimpin tindakan nyata dapat dipertanggungjawabkan atas perbuatan yang dilakukan oleh korporasi (PT).

Pengurus korporasi(PT) seperti direktur PT jika dalam keadaan "sebagai keadaan orang bertindak sebagai pemimpin kegiatan dalam tindak pidana”, artinya, keadaan seorang direktus korporasi (PT) yang bisa dalam keadaan sebagai pemberi perintah untuk melakukan tindak pidana dan juga dapat dalam keadaan sebagai pemberi perintah untuk melakukan tindak pidana dan juga dalam keadaan sebagai orang yang bertindak sebagai pemimpin kegiatan dalam tindak pidana.

Rumusan Pasal 116 ayat (1) huruf b dan Pasal 116 ayat (2) menggunakan kata atau frasa "atau" diantara frasa "orang yang memberi perintah untuk melakukan tindak pidana" dengan frasa "orang yang bertindak sebagai pemimpin kegiatan dalam tindak pidana"merupakan penegasan untuk mencegah dituntutnya dua kali seorang pengurus atau satu tindak pidana lingkungan yang terjadi. Pengurus Korporasi (PT) merupakan individu-individu yang mempunyai kedudukan atau kekuasaan sosial, setidaknya dalam lingkungan Perseroan Terbatas (PT) tempat mereka bekerja. Mereka-mereka yang dapat dikategorikan sebagai pengurus atau personal pengendali (directing mind atau controlling mind) korporasi adalah:

1. Mereka yang menurut anggaran dasarnya secara formal menjalankan pengurusan korporasi (PT);

2. Mereka sekalipun menurut anggaran dasar korporasi bukan pengurus, tetapi secara resmi memiliki kewenangan untuk melakukan perbuatan yang mengikat korporasi (PT) secara hukum berdasarkan:' pertama, Pengangkatan oleh pengurus untuk memangku satu jabatan dengan kewenangan untuk mengambil keputusan sendiri dalam batas ruang lingkup tugas dan kewajiban yang melekat pada jabatannya itu untuk dapat melakukan perbuatan hukum yang mengikat korporasi (PT), atau: kedua, Pemberian kuasa oleh pengurus atau mereka sebagaimana dimaksud (a)untuk dapat melakukan perbuatan yang secara hukum mengikat korporasi, atau: 
3. Oleh orang lain yang diperintahkan oleh mereka yang disebut dalam huruf (1) dan (2), untuk melakukan atau menjalankan pengurusan korporasi (PT).

Pengurus seperti Direktur PT adalah merupakan organ korporasi (PT) yang menjalankan kepungurusan Perseroan Terbatas yang bersangkutan sesuai dengan Anggaran Dasar, termasuk mereka yang dalam kenyataannya memiliki kewenangan dan ikut memutuskan kebijakan Perseroan Terbatas yang dikualifikasikan sebagai tindak pidana. Dengan demikian setiap individu yang ditunjuk memiliki tanggungjawan organisasi atau operasional untuk spesifik perilaku atau kewajiban untuk mencegah, suatu pelanggaran oleh Perseroan Terbatas dalam hal melaksanakan kewajiban untuk melakukan perlindungan dan pengelolaan lingkungan hidup sebagaimana diatur di dalam Pasal 68 UUPPLH dapat dimintakan pertanggungjawaban pidana atas terjadinya tindak pidana lingkungan khususnya pencemaran baku mutu lingkungan.

\section{Pertanggungjawaban Pidana Direktur Mewakili Organ Perseroan Terbatas Atas Perusakan Lingkungan Hidup}

Pasal 92 ayat (1) UU No. 40 Tahun 2007 tentang Perseroan Terbatas menyebutkan tanggung jawab Direksi: "Direksi menjalankan pengurusan Perseroan untuk kepentingan Perseroan dan sesuai dengan maksud dan tujuan Perseroan". ${ }^{13}$ Melihat tanggung jawab dan posisi Direksi tersebut diatas menunjukan bahwa keberadaan Direksi dalam suatu perseroan merupakan keharusan karena sebagai "artificial person" tidak dapat berbuat apa-apa tanpa adanya Direksi sebagai "natural person". ${ }^{14}$

Hubungan antara Perseroan dengan Direksi terlihat bukan sebagai hubungan atas dasar perjanjian kerja sebagaimana diatur dalam Pasal 1601 KUHPerdata dan juga tidak dapat diartikan sebagai hubungan antara Majikan dengan pekerja, seperti yang digambarkan oleh Imam Soepomo sebagai bekerja pada pihak lainnya berarti bekerja dibawah pimpinan pihak lain (majikan) dan karena kewajiban pekerja adalah melakukan pekerjaan menurut petunjuk dari Majikan. ${ }^{15}$ Hubungan antara Perseroan dengan Direksi lebih Nampak pada hubungan perwakilan, yaitu Direksi mewakili perseroan dan dengan itikad baik dan bertanggungjawab menjalankan tugas untuk kepentingan dan usaha perseroan (Pasal 92 ayat (1) UUPT).

Menurut Hartono Soerjopraktikno "Perwakilan dapat timbul dari perbuatan, yang sengaja bermaksud menimbulkan akibat itu (latsgeting machitiging)". Pemahaman mengenai perwakilan yang diuraikan diatas apabila dicermati dapat dirinci menjadi: pertama, Perwakilan yang berdasarkan kehendak lahir dari perjanjian: kedua: Perjanjian yang berdasarkan karena bukan kehendak dalam arti yang lahir dari undang-undang. ${ }^{16}$

Perwakilan dalam hubungan antara Perseroan dengan Direksi termasuk dalam pengertian perwakilan yang lahir bukan karena perjanjian, melainkan lahir karena ketentuan undang-undang. Tugas seorang Direksi secara rinci telah dirumuskan dalam Anggaran Dasar, sehingga dalam bertindak atau berbuat dalam hukum tentang Direksi harus selalu menguji tindakannya sebagaimana diatur di dalam Anggaran Dasar.

Tanggung jawab Direksi Perseroan erat kaitannya dengan sifat kolegialitas Direksi Perseroan. Menurut Pasal 98 ayat (1) UUPT, Direksi mewakili PT baik di dalam maupun di luar Pengadilan. Pasal 98 Ayat (2) UUPT menyebutkan bahwa dalam hal anggota Direksi terdiri lebih dari satu orang, yang berwenang mewakili PT adalah setiap anggota Direksi, kecuali

\footnotetext{
${ }^{13}$ Trusto Subekti, Batasan Tanggung Jawab Direksi Atas Kerugian Perusahaan, Fakultas Hukum Universitas Jenderal Sudirman, Jurnal Dinamika Hukum, Vol 8 No 1 Januari 20o8, hlm. 23

${ }^{14}$ Ibid

${ }^{15}$ I.G Rai Widjaya, 2001, Hukum Perusahaan, Djambatan, Jakarta, hlm 92.

${ }^{16}$ Imam Soeparno, 2001, Hukum Perburuhan Bidang Hubungan Kerja, Djambatan, Jakarta, hlm 92
} 
ditentukan lain dalam anggaran dasar mewikili PT adalah setiap anggota Direksi, kecuali ditentukan lain dalam anggaran dasar. Pasal 98 ayat (3) UUPT mengatakan bahwa kewenangan Direksi mewakili PT adalah tidak terbatas dan tidak bersyarat, kecuali ditentukan lain dalam UU, AD atau Keputusan RUPS.

Ketentuan Pasal 98 ayat (2) UUPT tersebut di atas memberikan petunjuk bahwa Lembaga Direksi PT dalam sistemnya bersifat kolegial, artinya, Direksi PT itu seharusnya terdiri dari lebih satu orang atau berbentuk Dewan. Sekalipun di dalam struktur organisasi diatur adanya Direktur Utama, Direktur Personalia, Direktur Kepatuhan, Direktur Produksi dan lain sebagainya, tidak berarti bahwa kedudukan Direktur Utama lalu menjadi lebih, kedudukannya sederajat. Mereka adalah Dewan, kolegial. Sistem tanggung jawabnya pada dasarnya Bersama-sama atau tanggung renteng.

Dengan demikian Pasal 98 ayat (2) UUPT mengatur siapa yang berwenang mewakili PT yaitu setiap anggota Direksi, kecuali ditentukan lain dalam Anggaran Dasar. Bahkan dari sudut pandang doktrin, kedudukan masing-masing organ PT (RUPS, Dewan Komisaris dan Direksi) pada asasnya satu sama lain mempunyai kedudukan yang sama atau sejajar, yang satu tidak berada di bawah yang lain, masing-masing mempunyai tugas sendiri-sendiri yang diberikan oleh UU dan/atau Anggaran Dasar.

Ketentuan mengenai pertanggungjawaban pidana direksi dapat terjadi dalam hal karyawan bawahan melanggar atau tidak melakukan hal yang menjadi kewajiban korporasi (PT) sehingga menimbulkan tindak pidana, maka direktur atau karyawan tersebut dapat dimintai pertanggungjawaban secara individu, dan korporasi (PT) juga dianggap melakukan tindak pidana serta dapat dimintai pertanggungjawaban pidana atas dilanggarnya kewajibankewajiban tersebut. Selanjutnya, terdapat juga pertanggungjawaban pidana individu direksi atas pelanggaran yang dilakukan oleh perusahaan, tanpa perlu untuk membuktikan apakah direksi telah memenuhi unsur-unsur mental (misalnya, pengetahuannya, niat, atau kelalaian) dari pelanggaran tersebut. ${ }^{17}$

Alvi Syahrin berpandapat, bahwa pertanggungjawaban pidana bagi pejabat korporasi (PT) yaitu Direksi yang berada dalam posisi pertanggungjawaban (pengurus korporasi) berdasarkan Responsible Corporate Officer Doctrine (RCO) dan Strict Liability, ditegaskan bahwa pejabat perusahaan dapat bertanggungjawab atas tindak pidana korporasi (PT), meskipun ia tidak mengetahui adanya tindak pidana tersebut, oleh karena posisinya dalam perusahaan memiliki kewajiban untuk mengambil tindakan untuk memastikan bahwa pelanggaran tersebut tidak akan terjadi. Pejabat korporasi (PT) dimintai pertanggungjawaban secara pribadi atas tindak pidana korporasi selama pejabat itu memiliki wewenang untuk mencegah terjadinya pelanggaran atau untuk memperbaiki keadaan. Pertanggungjawaban pidana terhadap pejabat tersebut tidak perlu memperhatikan (dibuktikan lagi) adanya mens rea, sebab mens rea, telah terbukti karena pejabat tersebut telah melanggar kewajibannya tersebut. ${ }^{18}$

Selanjutnya rumusan Pasal 116 ayat (1) huruf b dan Pasal 116 ayat (2) UUPPLH menggunakan kata /frasa "atau" diantara frasa "orang yang memberi perintah untuk melakukan tindak pidana "dengan frasa "orang yang bertindak sebagai pemimpin kegiatan dalam tindak pidana" merupakan penegasan untuk menengah dituntutnya dua kali seorang pengurus atas satu tindak pidana lingkungan yang terjadi.

Pengurus merupakan organ korporasi (PT) yang menjalankan kepungurusan korporasi (PT) yang bersangkutan sesuai dengan anggaran dasar, termasuk mereka yang dalam kenyataannya memiliki kewenangan dan ikut memutuskan kebijakan korporasi (PT) yang dapat dikualifikasikan sebagai tindak pidana. Dengan demikian, setiap individu yang ditunjuk

\footnotetext{
${ }^{17}$ Ibid

${ }^{18}$ Ibid
} 
sebagai memiliki tanggungjawab organisasi atau opersional spesifik perilaku atau yang memiliki kewajiban untuk mencegah, suatu pelanggaran oleh korporasi (PT) dalam hal ini melaksanakan kewajiban untuk melakukan perlindungan dan pengelolaan lingkungan hidup sebagaimana diatur Pasal 68 UUPPLH. ${ }^{19}$

Berdasarkan Pasal 116 ayat (1) UUPPLH, dalam hal tindak pidana dilakukan oleh, untuk dan atas nama badan usaha, yang dapat dituntut dan dijatuhkan hukuman, yaitu;

1. Badan usaha dan orang yang memberi perintah untuk melakukan tindak pidana lingkungan:

2. Badan usaha dan orang yang bertindak sebagai pemimpin kegiatan dalam tindak pidana lingkungan;

3. Badan usaha;

4. Orang yang memberi perintah untuk melakukan tindak pidana lingkungan;

5. Orang yang bertindak sebagai pemimpin kegiatan dalam tindak pidana.

Ketentuan Pasal 116 ayat (1) UUPPLH membuka kemungkinan apabila suatu korporasi melakukan perbuatan pidana, tidak hanya yang dituntut korporasinya saja, tetapi juga orang yang telah memerintahkan kejadian tersebut dan orang yang memimpin sendiri secara nyata dapat dipertanggungjawabkan atas perbuatan yang dilakukan oleh korporasi (PT). Pernyataan di atas sangat sesuai, dimana dalam perwakilan mengenai siapa yang menurut hukum sebagai yang melakukan perbuatannya, dalam arti dilakukan oleh si wakil atau oleh orang yang diwakili, terdapat 3 (tiga) teori yang dijelaskan oleh Hartono Soerpraktiknyo, sebagai berikut: ${ }^{20}$

1. Teori representasi atau fiksi, bahwa si wakillah yang melakukan perbuatan. Dia tidak hanya berbuat/bertindak realiter, tetapi juga dialah yang yuridis menyatakan kehendaknya. Berdasarkan suatu fiksi maka akibat hukum dari perbuatannya tindakannya dipindahkan pada prinsipalnya :

2. Teori Organ (nuntius-theori) yang melihat si wakil, person (pribadi) yang berbuat menurut hukum. Si wakil hanyalah organ yang tersedia untuk orang yang diwakili, yang kehendaknya untuk terjadinya hubungan hukum itu adalah menentukan;

3. Teori koperasi, yang merupakan kombinasi dari teori representasi dan teori organ perbuatan yang dilakukaan oleh si wakil atas nama principal terjadi di kerena sesungguhnya ada Kerjasama yuridis antara wakil dan orang yang diwakili.

Pengurus korporasi (PT) dapat dalam keadaan "sebagai orang yang memberi perintah untuk melakukan tindak pidana", atau pengurus korporasi (PT) dapat dalam keadaan "sebagai orang yang bertindak sebagai pemimpin kegiatan dalam tindak pidana". Artinya, keadaan seorang pengurus PT yang bisa dalam keadaan si pemberi perintah untuk melakukan tindak pidana dan juga bisa dalam keadaan sebagai orang yang bertindak sebagai pemimpin kegiatan dalam tindak pidana. ${ }^{21}$

Keadaan seorang pengurus sebagai pemberi perintah untuk melakukan tindak pidana dan juga bisa sebagai orang yang bertindak sebagai pemimpin kegiatan dalam tindak pidana akan menyebabkan pengurus tersebut dapat dituntut dua kali. Menuntut pengurus sebagai pemberi perintah untuk melakukan tindak pidana dan juga bisa sebagai orang yang bertindak sebagai pemimpin kegiatan dalam tindak pidana, akan bertentangan dengan rasa keadilan dan juga asas ne bis in idem akan menjadi penghalang untuk menuntut dua kali orang (pengurus) yang sama dalam keadaan berbeda-beda (sebagai pemberi perintah untuk melakukan tindak pidana dan juga bisa sebagai orang yang bertindak sebagai pemimpin kegiatan dalam tindak pidana), artinya terhadap pengurus tersebut cukup ditentukan keadaan sebagai pemberi

\footnotetext{
${ }^{19}$ Ibid

${ }^{20}$ Soerjopraktikno Hartono,1994, Perwakilan Berdasarkan Kehendak, Mustika Wikasa, Yogjakarta, hlm. 5-12.

${ }^{21}$ Ibid
} 
perintah untuk melakukan tindak pidana atau keadaan sebagai orang yang bertindak sebagai pemimpin kegiatan dalam tindak pidana. ${ }^{22}$

Berdasarkan Pasal 116 ayat (1) huruf a UUPPLH, terdapat kata "dan/atau”. Kata "dan/atau" tersebut menggambarkan bahwa jika di gunakan kata "dan" maka tuntutan pidana dan sanksi pidana dijatuhkan kepada :

1. Badan usaha dalam hal ini korporasi (PT); dan

2. Orang yang memberi perintah untuk melakukan suatu tindak pidana tersebut atau orang yang bertindak sebagai pemimpin kegiatan dalam tindak pidana tersebut, artinya, badan usaha atau korporasi (PT) dapat dituntut pidana dan dijatuhi pidana.

Selanjutnya ketentuan Pasal 118 UUPPLH, juga telah mempertegas bahwa badan usaha atau korporasi (PT) dapat dituntut pidana dan dijatuhi pidana, didalamnya terdapat kata "yang diwakili oleh pengurus yang berwenang mewakili di dalam dan di luar pengadilan sesuai dengan peraturan perundang-undangan selaku pelaku fungsional" adalah untuk menegaskan bahwa badan usaha seperti PT pada waktu dituntut di pengadilan, yang mewakilinya adalah pengurus yang berwenang mewakili di dalam di luar pengadilan sesuai dengan peraturan perundang-undangan.

\section{D.Kesimpulan}

Pertanggungjawaban pidana dapat dimintakan kepada korporasi (PT) atas perusakan lingkungan hidup sebagaimana diatur dalam Pasal 116 ayat (1) UUPPLH. Pertanggungjawaban Pidana korporasi (PT) dimintakan tanpa melihat adanya kesalahan (Strict Liability). Pertanggungjawaban pidana direktur PT mewakili organ perseroan terbatas atas tindak pidana perusakan lingkungan hidup dapat diidentifikasikan Responsible Corporate Officer Doctrine (RCO) dan Strict Liability, bahwa pejabat korporasi (PT) dapat dimintakan pertanggungjawaban pidana meskipun ia tidak mengetahui tindak pidana tersebut. Hal ini posisi direktur dalam Perseroan Terbatas memiliki kewajiban untuk mengambil Tindakan untuk memastikan bahwa pelanggaran tidak akan terjadi. Direktur Perseroan Terbatas dapat dimintakan pertanggungjawaban pidana secara pribadi atas tindak pidana korporasi (PT) selama pejabat itu memiliki wewenang untuk mencegah terjadinya pelanggaran atau memperbaiki keadaan. Pertanggungjawaban pidana direktur PT tersebut tidak perlu memperhatikan pembuktian akan adanya mensa rea, sebab mens rea telah terbukti telah melanggar kewajiban tersebut.

\section{Daftar Pustaka}

Andi Hamzah, 2005, Penegakan Hukum Lingkungan, Jakarta, Sinar Grafika

Alvi Syahrin, dkk, 2019, Ketentuan Pidana Korporasi Tentang Perlindungan dan Pengelolaan Lingkungan Hidup, Jakarta, Kencana

Alvi Syahri, 2019, Pertanggungjawaban Pidana Korporasi dalam Undang-Undang No 32 Tahun 2019 tentang Perlindungan dan Pengelolaan Lingkungan Hidup, Makalah Disampaikan pada "Simposium Nasional, Pelatihan Hukum Pidana dan Kriminologi" MAHUPIKI, 3 April 2018, Padang

Dyah Ochtorina Susanti, A' an Efendi, 2014, Penelitian Hukum (Legal Research), Sinar Grafika, Jakarta

Imam Soeparno, 2001, Hukum Perburuhan Bidang Hubungan Kerja, Djambatan, Jakarta

Soerjopraktikno Hartono,1994, Perwakilan Berdasarkan Kehendak, Mustika Wikasa, Yogjakarta I.G Rai Widjaya, 2001, Hukum Perusahaan, Djambatan, Jakarta

\footnotetext{
${ }^{22}$ Ibid
} 
Jurnal Magister Hukum Program Pascasarjana Universitas HKBP Nommensen

Volume 02 Nomor 02 Juli 2021 Halaman. 143-155 e-ISSN: 2723-164X p-ISSN: 2722-9858

http://ejournal.uhn.ac.id/index.php/opinion

Simamora, Janpatar., Tafsir Makna Negara Hukum dalam Perspektif Undang-Undang Dasar Negara Republik Indonesia Tahun 1945, Jurnal Dinamika Hukum FH Universitas Jenderal Soedirman, Vol. 14 No. 3 September 2014, hlm. 547-561

Simamora, Janpatar., Analisa Yuridis Terhadap Model Kewenangan Judicial Review di Indonesia, Jurnal Mimbar Hukum Fakultas Hukum Universitas Gadjah Mada Yogyakarta, Vol. 25 No. 3 Oktober 2013, hlm. 388-401.

Johnny Ibrahim, 2006, Teori dan Metodologie Penelitian Hukum Normatif, Bayumedia, Surabaya

Mulyadi dan Dwidja Priyatno, Pertanggungjawaban Pidana Korporasi, Prenada, Jakarta

Mulyadi dan Dwidja Priyatno, 1991, Pertanggungjawaban Pidana Korporasi Dalam Hukum Pidana, , Sekolah Tinggi Hukum, Bandung

N.H.T. Siahaan, 2009, Hukum Lingkungan, Pancuran Alam, Jakarta.

Soerjono, Soekanto dan Sri Mamudji, Penelitian Hukum Normatif, Suatu Tinjauan Singkat, Raja Grafindo Persada, Jakarta, 1995

Trusto Subekti, Batasan Tanggung Jawab Direksi Atas Kerugian Perusahaan, Fakultas Hukum Universitas Jenderal Sudirman, Jurnal Dinamika Hukum, Vol 8 No 1 Januari 2008

Tony Samuel, Penerapan Tindak Pidana Lingkungan Bagi Korporasi Dalam Penegakan Hukum Lingkungan, Socioscientia Jurnal Ilmu Ilmu Sosial, Volume 8 No 1 Maret 2016

UU No 32 Tahun 2009 tentang Perlindungan dan Pengelolaan Lingkungan Hidup (UUPPLH) 